\title{
Electron Microscope Observations of Brucella abortus Grown within Monocytes in vitro
}

\author{
By GIOANNA KARLSBAD, R. W. I. KESSEL, S. DE PETRIS and \\ L. MONACO \\ Laboratory of Electron Microscopy, Clinica del Lavoro 'L. Devoto', \\ University of Milan, Italy
}

(Received 28 October 1963)

\begin{abstract}
SUMMARY
Cells of Brucella abortus, strain SA-s, grown within normal guinea-pig monocytes maintained in vitro, were examined by electron microscopy. Intracellular multiplication of brucellae was followed for $48 \mathrm{hr}$. During the entire period of observation the bacteria were present in the cytoplasm of the monocytes, localized within vacuoles limited by a 'unit membrane'.

No obvious ultrastructural differences (particularly in surface structures) were detected between monocyte-grown bacteria and sister cells cultivated on a lifeless medium, which might account for the known differences between the two (e.g. differences in resistance to serum bactericidal factors and in intracellular growth patterns).

In spite of the large numbers of intracellular parasites present the host cells did not show evident structural modifications.

Some observations made on intracellular $B$. abortus, strain SA-R, showed that after up to $24 \mathrm{hr}$ within guinea-pig monocytes most of the bacteria had retained their morphological integrity and were indistinguishable from $\mathbf{R}$ organisms grown on agar.
\end{abstract}

\section{INTRODUC'TION}

The previous paper (de Petris, Karlsbad \& Kessel, 1964) reported the morphological features of Brucella abortus as seen in electron micrographs of thin sections. No ultrastructural differences were observed between $S$ and $\mathrm{R}$ variants of $B$. abortus, strain SA, grown on a lifeless medium.

In addition to the differences that have long been known to exist between $S$ and $\mathbf{R}$ types, there has in recent years been increasing awareness of the differences between pathogenic bacteria grown on lifeless media and sister cells grown within tissue cells (for example see Smith, 1960; Beining \& Kennedy, 1963). In studies involving Brucella abortus, Stinebring, Braun \& Pomales-Lébron (1960) detected differences in the sensitivity to serum bactericidal factors between brucellas grown on lifeless media ('slant grown cells') and sister cells grown within guinea-pig monocytes maintained in vitro ('monocyte-grown cells'). In addition Stinebring \& Kessel (1959) had observed differences in intracellular growth patterns between slant-grown and monocyte-grown brucellas and recently Stinebring (1962) has reported on differences in rate of phagocytosis and intracellular survival between these two phenotypes. The large mononuclear phagocytic cell found in spontaneous or induced peritoneal exudates has been given many names including 'macrophage', 
'wandering histiocyte' and 'monocyte'. We will use this last term in conformity with previous studies on the intracellular growth of $\boldsymbol{B}$. abortus in vitro.

As related studies had provided us with techniques for the electron microscope examination of thin sections of tissue culture monolayers, we took occasion to examine $\mathbf{S}$ cells of Brucella abortus during their multiplication within monocytes maintained in vitro. In addition this system allowed us also to study the events occurring within the tissue cell during the intracellular multiplication of the brucellas. For purpose of comparison some observations were also made on monocytes infected with a closely related avirulent $B$. abortus (strain SA-R).

\section{METHODS}

Brucella abortus, strains SA-s and SA-R and its cultivation on a lifeless medium were described in the preceding paper (de Petris et al. 1964).

To study the intracellular growth of brucellas, monolayer cultures of guinea-pig peritoneal monocytes were infected, established and maintained in vitro by methods previously described (Pomales-Lébron \& Stinebring, 1957) which limit all multiplication to the intracellular environment. The only modification was that monocytes were mobilized by an intraperitoneal injection of $20 \mathrm{ml} .0 .9 \%(\mathrm{w} / \mathrm{v})$ aqueous sodium chloride 2 days prior to their collection. Leighton tubes $(1 \times 4 \mathrm{~cm}$., Bellco Glass Co., Vineland, N.J., U.S.A.) were used, a movable floor being provided by the insertion of a glass microscope slide cut to the appropriate size. Fixation in $\mathrm{OsO}_{4}$ buffered according to Palade (1952) or Kellenberger, Ryter \& Séchaud (1958) failed to give satisfactory preservation of brucellas in monocytes. Good preservation both of brucellas and monocytes was obtained by fixing with $2 \%(\mathrm{w} / \mathrm{v}) \mathrm{KMnO}_{4}$ in distilled water for $1 \mathrm{hr}$, followed by buffered $1 \%(\mathrm{w} / \mathrm{v}) \mathrm{OsO}_{4}$ (Palade, 1952) for $1 \mathrm{hr}$. The monolayers were finally post-fixed with $1 \%(\mathrm{w} / \mathrm{v})$ uranyl acetate in distilled water for $1 \mathrm{hr}$.

Dehydration and embedding in Araldite were performed as described in the previous paper, except that all the intermediate steps were carried out in small Petri dishes containing the glass slides covered with their monolayers. Finally, gelatin capsules, filled with Araldite, were inverted over the monolayers (after the most suitable areas had been selected using the light microscope). The capsules were allowed to polymerize at $80^{\circ}$. After about $48 \mathrm{hr}$ the embedded monolayers were stripped off the glass either mechanically or by placing the slides over solid $\mathrm{CO}_{2}$ which caused the capsules to detach spontaneously. Occasionally the monolayers were re-embedded to permit their re-orientation. Thin sections were cut with a Servall Porter-Blum microtome and examined with a Siemens Elmiskop I electron microscope. Some difficulty was encountered in the actual sectioning of the monolayers probably because of the different hardness of the bacteria and the material surrounding them.

\section{Brucella abortus, strain SA-s}

\section{RESULTS}

Monolayers of monocytes with and without intracellular brucellas were examined 2, 24 and $48 \mathrm{hr}$ after initial exposure to brucellas. Longer times were not feasible because the number of surviving monocytes in the monolayers was so reduced as to make observation in thin sections impractical. 
After $2 \mathrm{hr}$ the monocytes were seen to contain a few brucellas enclosed in one or more phagocytic vacuoles which were surrounded by a typical 'unit membrane' (Robertson, 1959). Often the vacuoles contained traces of other substances. Except for the presence of the brucellas the appearance of the monocytes at this stage was indistinguishable from that of control monocytes.

Twenty-four hours after inoculation of the tissue culture no appreciable structural changes were noted either in the host cells or in the brucellas; the only difference was the increased number of brucellas. The organisms were always confined to the cytoplasm; in a few sections they could be demonstrated in the region of the nuclear indentation, but usually they did not invade the Golgi complex. They were invariably enclosed with vacuoles which were surrounded by normal looking cytoplasm. Plate 1, fig. 1, shows a typical monocyte fixed $24 \mathrm{hr}$ after exposure to the bacteria. Apparently there has been considerable intracellular multiplication and all the progeny of the initially ingested brucellas appear to lie within vacuoles which are surrounded by a membrane. The structure of the monocytes appeared otherwise unmodified.

After $48 \mathrm{hr}$ the appearance of the monocytes was very similar to that of the cells after $24 \mathrm{hr}$. The cellular architecture (Golgi complex, mitochondria and nucleus, which is often displaced peripherally) remained relatively unaffected by the large number of intracellular brucellas present (Pl. 3, fig. 4). The latter were still enclosed within vacuoles contained within a 'unit membrane' (Pl. 3, fig. 3).

Plate 4, fig. 6, and PI. 3, fig. 5, are higher magnifications of brucellas after 24 and $48 \mathrm{hr}$ of intracellular growth (a time sufficient to allow for the changes from slant-grown to monocyte-grown to occur). The ultrastructure of these brucellas was identical to that of the slant-grown organisms (de Petris et al.1964). The cell wall and cytoplasmic membrane appeared unchanged and were clearly outlined; there was no evidence of capsular material external to the cell wall. The overall dimensions of the outer cell wall layer and plasma membrane were comparable, but in some cases the dense layers constituting the plasma membrane appeared thinner and less electron opaque. As a rule the cytoplasmic membrane was better preserved and more clearly outlined in monocyte-grown than in slant-grown organisms, possibly because in the monocyte there was greater protection against extraction of material during the preparation of the sample for electron microscopy. It may be noted that, under the conditions of fixation employed, the appearance of the outer cell wall layer of the brucellas was in many cases indistinguishable (in dimensions and electron density) from the 'unit membrane' round the vacuole enclosing the organisms (Pl. 4, fig. 6).

Peripheral formations (de Petris et al. 1964) were rarely observed. 'Cytoplasmic retraction' with widening of the amorphous inner cell wall layer ( $\mathrm{Pl}$. 4, fig. 6), on the other hand, was frequently noted.

In some monocytes containing many brucellas with smooth outlines some denser organisms with irregular contours were occasionally found, either sharing a vacuole with normal looking bacteria, or lying in adjacent vacuoles (Pl. 2, fig. 2). The wide empty space surrounding such brucellas suggests that these images result from shrinkage artifacts limited, for unknown reasons, to these particular bacteria.

After 24, and, even more frequently, after $48 \mathrm{hr}$ some membranous formations were often present inside vacuoles either surrounding or adjacent to the brucellas; 
these structures were at times arranged concentrically in fairly regular 'myelin figures' (Pl. 2, fig. 2; Pl. 3, fig. 3). They were made up of triple-layered membranes, indistinguishable in structure both from the bacterial outer cell wall layer and from the 'unit membrane' of the vacuole. Some vacuoles also contained some dense amorphous or flocculent material.

Numerous rounded, smooth or slightly wrinkled, cytoplasmic bodies about $1 \cdot 0$ $1.5 \mu$ diam. (Pl. 1, fig. 1; Pl. 3, fig. 3) were invariably present in the monocytes in our cultures. In the $\mathrm{OsO}_{4}$ fixed preparations they appeared electron opaque and perfectly homogeneous in texture, while in the cells fixed with $\mathrm{KMnO}_{4}$ their appearance was more granular and denser and they usually presented a darker outer shell. They were not enclosed in a vacuole and recalled (particularly in the $\mathrm{OsO}_{4}$ fixed preparations) the lipid inclusions observed in other types of cells.

\section{Brucella abortus, strain SA-R}

In some experiments monocytes were exposed to Brucella abortus, strain SA-R, for 2 and $24 \mathrm{hr}$. Longer times were not feasible because in these experiments the monocytes infected with brucellas, strain SA-R, underwent degeneration much more rapidly than parallel cultures infected with the same inocula of strain sA-s. These observations remain unexplained, but recall similar findings reported by Freeman, Kross \& Circo (1961).

As a rule after 2 or $24 \mathrm{hr}$ the monocytes appeared unaffected by the presence of bacteria in their cytoplasm. The brucellas themselves, which were always enclosed within vacuoles, also appeared unaltered and practically indistinguishable from strain sA-s brucellas (Pl. 4, fig. 7). In some monocytes a few brucellas, still inside a phagocytic vacuole, appeared to be undergoing degeneration (Pl. 4, fig. 8). Some vacuoles were filled with fragments of such brucellas recognizable by their general structure or by remnants of cell wall. The monocytes containing such degenerating organisms appeared unaltered in structure.

Both in the $\mathbf{S}$ and $\mathbf{R}$ cultures some monocytes were present which had reached very advanced stages of degeneration; it was interesting to note in some of these cells the presence of normal looking brucellas, either still enclosed within vacuoles or lying free in the grossly disorganized cytoplasm.

\section{DISCUSSION}

The present investigation had two aims: first, a search for possible morphological alterations following the transfer of cells of Brucella abortus from a lifeless medium to the intracellular environment; and secondly, a study of the events occurring within the tissue cell as a consequence of the intracellular multiplication of virulent brucellas. Stinebring et al. (1960) reported that cells of $\boldsymbol{B}$. abortus grown on tryptose agar were more susceptible to the lethal action of normal serum than sister cells cultivated within guinea-pig peritoneal monocytes maintained in vitro. As Michael $\&$ Braun $(1959 a, b)$ had previously reported that among members of the Enterobacteriaceae differences in sensitivity to the bacterial activity of normal sera were associated with differences in cell wall structure, it seemed at least possible that the differences observed in brucellas might have a morphological basis.

Examination of thin sections of intracellular brucellas has revealed, however, no 
differences in morphology associated with intracellular growth. It seems likely therefore that the known differences between slant-grown and cell-grown brucellas, if they involve changes in surface structures, are associated with modifications which are not detectable with the electron microscope. The changes in serum sensitivity in brucellas may be more closely related to differences in biochemical make-up such as those reported by Michael \& Braun (1959 $a, b)$.

The morphological events occurring within the monocyte following infection by virulent Brucella abortus have received relatively little attention in the past, although a number of different laboratories have developed tissue culture methods for the examination of this host-parasite system. It has not been clear hitherto whether intracellular brucellas exist free in the cytoplasm or lie localized in vacuoles within the cell. Although Richardson (1959) reported that Brucella abortus appeared to be localized in discrete 'packets' within tissue cells she added that it was impossible for her to exclude shrinkage artifacts. Most workers would probably agree that the nucleus is never invaded and that the cell maintains its characteristic morphology until it bursts. Our work confirms and extends this opinion. The phagocytosed brucellas are indeed confined to the cytoplasm, where they lie enclosed within vacuoles throughout the life of the monocyte. However, our observations were limited to $48 \mathrm{hr}$ periods of intracellular bacterial growth, and our conclusions might not apply therefore after longer incubation of the monocytes.

The architecture of the tissue cell outside the vacuoles appears to be completely unaffected. On examining sections which do not cut through brucellas, it is often impossible to decide whether the cell is infected or uninfected. As a monocyte in this test system may ingest as many as ten brucellas each of which may go through many division cycles within the $48 \mathrm{hr}$ cultivation period, this resistance of the tissue cell is indeed remarkable, and may be related to the localization of the brucellas within the expanding phagocytic vacuole. A review of the literature suggests that this may be so. Thus Bacillus anthracis, which leads to marked cytopathic changes in the cell, apparently lies free in the cytoplasm and not enclosed within a vacuole (Roth, Lewis \& Williams, 1960; Roth \& Williams, 1963). This appears to be true also of histoplasma (Edwards, Edwards \& Hazen, 1959), in leptospira infections (Miller \& Wilson, 1962), and possibly in those of the psittacosis group (Tajima, Nomura \& Kubota, 1957; J. Moulder, personal communication). On the other hand the pleuropneumonialike organisms (Edwards \& Fogh, 1960), the tubercle bacillus (Brieger \& Glauert, 1956) and leprosy bacilli (Chapman, Hanks \& Wallace, 1959; Imaeda \& Convit, 1961) which, like brucellas, do not show any great cellular toxicity, are restricted to a vacuole.

The localization of brucellas within a vacuole may be related to the fact that intracellular bacteria are no longer susceptible to the action of extracellular antibiotics or of antibody (Gelzer \& Suter, 1959), though the physical exclusion of these substances from the host cell seems unlikely. Similarly, it seems unlikely that tissue cells possess the ability to inactivate a large number of different bactericidal or bacteriostatic agents. On the basis of the present findings it would seem more likely that the latter remain spatially separated from the bacteria, and this is supported by the observation that bacteria within intracellular vacuoles (see above) appear to be less susceptible to the action of 'extracellular' antibiotics than those which lie free in the cytoplasm. However, Richardson \& Holt (1962) recently demonstrated 


\section{G. Karlsbad, R. W. I. Kessel, S. De Petris and L. Monaco}

that 5-50 $\mu \mathrm{g}$. streptomycin $/ \mathrm{ml}$. in the extracellular medium, which alone did not affect the intracellular growth of Brucella abortus, was lethal when used in conjunction with $50 \mu \mathrm{g}$. penicillin $/ \mathrm{ml}$. A hypothesis based on spatial separation would therefore seem to be inadequate to explain the resistance to antibiotics of vacuoleenclosed organisms. Although one cannot exclude that the concentration of antibiotic inside the vacuole may be lower than in the adjacent cytoplasm, bacterial susceptibility probably depends also on metabolic factors related to the particular environment of the organisms. For example, the resistance of Salmonella typhi to antibiotics is related to the composition of the suspending medium as well as to the phase of bacterial growth (Hopps et al. 1961).

It is not known at present whether the multiplication of intracellular brucellas is accompanied by continuous synthesis of the enclosing vacuole's membrane. This is likely because the synthesis of membrane appears to be a fairly common reaction of cells to a variety of external and internal stimuli. An increased rate of production of the membrane is also suggested by the membranous structures of different shapes frequently observed in vacuoles containing brucellas, which appear at times to surround individual organisms, isolating them from each other inside the original vacuole. Although these membranous structures might be derived from remnants of dead brucellas, they are often present in too large amounts to be accounted for entirely in this way. The final destruction of the monocyte may well be related to the incapacity of the cell to continue synthesizing membrane indefinitely for the expanding vacuoles. Should the surface area of the vacuole limit the number of enclosed brucellas, doubling of this number would cause the vacuole to rupture, resulting finally in the disorganization and destruction of the monocyte. In any case, from the normal appearance of the infected monocytes, it can be concluded that in this host-parasite system, the death of the host cell seems to depend on the numbers of bacteria lying within it, rather than upon a direct toxic activity of the parasites.

From a limited number of observations on intracellular avirulent brucellas it can be stated that, at least after $24 \mathrm{hr}$ (as regards their ultrastructure and their relation to the host cell) they appear indistinguishable both from slant-grown sister cells and from monocyte-grown virulent brucellas. The above observations indicate that monocytes do not exert a rapid bactericidal action on the avirulent brucellas; this is in accordance with the data of Stinebring \& Kessel (1959) who recovered an appreciable number of viable brucellas $\mathbf{R} 3$ days after infection of the monocytes (although in successive subcultures this number fell rapidly).

This study was carried out while one of us (R. W. I. Kessel) was a National Science Foundation Postdoctoral Fellow. He would like to thank Professor E. C. Vigliani (Director) and Professor B. Pernis of the Clinica del Lavoro 'L. Devoto' for their hospitality and help.

Grateful acknowledgement is also made to Dr Ann Heuer for helpful criticism of this manuscript. 


\section{REFERENCES}

Beining, P. R. \& Kennedy, E. R. (1963). Characteristics of a strain of Staphylococcus aureus grown in vivo and in vitro. J. Bact. 85, 732.

Brieger, E. M. \& Glauert, A. M. (1956). Electron microscopy of leprosy bacillus: a study of submicroscopic structure. Tubercle, 37, 195.

Chapman, G. B., Hanks, J. M. \& Wallace, J. M. (1959). Electron microscope study of the disposition and fine structure of Mycobacterium lepraemurium in mouse spleen. J. Bact. 77, 205.

de Petris, S., Karlsbad, G. \& Kessel, R. W. I. (1963). The ultrastructure of S and R variants of Brucella abortus grown on a lifeless medium. J. gen. Microbiol. 35,

Eowards, G. A., Edwards, M. R. \& Hazen, E. L. (1959). Electron microscopic study of histoplasma in mouse spleen. J. Bact. 77, 429.

Edwards, G. A. \& Fogh, J. (1960). Fine structure of pleuropneumonia-like organisms in pure culture and in infected tissue culture cells. J. Bact. 79, 267.

Freeman, B. A., Kross, D. J. \& Circo, R. (1961). Host-parasite relationships in brucellosis. II. Destruction of macrophage cultures by Brucella of different virulence. $J$. infect. Dis. 108, 333.

Gelzer, J. \& Suter, E. (1959). The effect of antibody on intracellular parasitism of Salmonella typhimurium in mononuclear phagocytes in vitro. Prolonged survival of infected monocytes in presence of antibody. J. exp. Med. 110, 715.

Hopps, H. E., Smadel, J. E., Bernheim, B. C., Danauskas, J. X. \& Jackson, E. B. (1961). Effect of antibiotics on intracellular Salmonella typhosa. II. Elimination of infection by prolonged treatment. J. Immunol. 87, 162.

Kellenberger, E., Ryter, A. \& Séchaud, J. (1958). Electron microscopic study of DNA-containing plasma. II. Vegetative and mature phage DNA as compared with normal bacterial nucleoids in different physiological states. J. biophys. biochem. Cytol. 4, 671 .

ImAEDA, T. \& ConviT, J. (1961). Electron microscope study of Mycobacterium leprae and its environment in a vesicular leprous lesion. $J$. Bact. 83, 43.

Michael, J. G. \& Braun, W. (1959a). Serum spheroplasts of Shigella dysenteriae. Proc. Soc. exp. Biol., N.Y. 100, 422.

Michael, J. G. \& BraUn, W. (1959 b). Modifications of bactericidal effect of human sera. Proc. Soc. exp. Biol., N.Y. 102, 486.

Miller, N. G. \& Wilson, R. B. (1962). In vivo and in vitro observations of Leptospira pomona by electron microscopy. J. Bact. 84, 569.

Palade, G. E. (1952). A study of fixation for electron microscopy. J. exp. Med. 95, 285.

Pomales-Lébron, A. \& Stinebring, W. R. (1957). Intracellular multiplication of Brucella abortus in normal and immune mononuclear phagocytes. Proc. Soc. exp. Biol., N.Y. 94, 78.

Richardson, M. (1959). Parasitization in vitro of bovine cells by Brucella abortus. J. Bact. 78, 769 .

Richardson, M. \& Holt, J. N. (1962). Synergistic action of streptomycin with other antibiotics on intracellular Brucella abortus in vitro. J. Bact. 84, 638.

Robertson, J. D. (1959). The ultrastructure of cell membranes and their derivatives. Biochem. Soc. Symp. 16, 3.

Roth, I. L., Lewis, C. W. \& Williams, R. P. (1960). Electron microscope study of Bacillus anthracis in mouse spleen. J. Bact. 80, 772.

Roth, I. L. \& Williams, R. P. (1963). Nature of cytopathic area surrounding virulent anthrax bacillus in mouse spleen. Bact. Proc. M. 152.

SmiтH, H. (1960). Studies on organisms grown in vivo to reveal the bases of microbial pathogenicity. Ann. N.Y. Acad. Sci. 88, 1213.

Stinebring, W. R. (1962). Characteristics of intracellularly grown Brucella abortus. J. infect. Dis. 111, 17.

Stinebring, W. R., Braun, W. \& Pomales-Lébron, A. (1960). Modified serum resistance of bacteria following intracellular residence. Ann. N.Y. Acad. Sci. 88, 1230. 
Stinebring, W. R. \& Kessel, R. W. I. (1959). Continuous growth of Brucella abortus in mononuclear phagocytes of rats and guinea pigs. Proc. Soc. exp. Biol., N.Y. 101, 412.

Tajima, M., Nomura, Y. \& Kubota, Y. (1957). Structure and development of viruses of the psittacosis-lymphogranuloma group observed in the electron microscope. J. Bact. 74, 605 .

\section{EXPLANATION OF PLATES}

\section{Plate 1}

Fig. 1. Guinea-pig monocyte $24 \mathrm{hr}$ after infection with Brucella abortus strain sA-s. Several brucellas are contained within membrane-bound vacuoles. Two dense cytoplasmic bodies (arrows), clearly distinct from brucellas, can be seen at the bottom of the micrograph. $\times 20,750$.

\section{Plate 2}

Fig. 2. Detail of the cytoplasm of a monocyte $24 \mathrm{hr}$ after infection with $B$. abortus, strain sA-s. The organisms are all enclosed within vacuoles. A shrunken-looking brucella surrounded by an empty space is present in the centre of the field next to some normal looking bacteria. $\times 53,000$.

\section{Plate 3}

Fig. 3. Detail of the cytoplasm of a monocyte $48 \mathrm{hr}$ after infection with $B$. abortus, strain sA-s. The brucellas are still enclosed within vacuoles (some of them show a slight degree of shrinkage). Concentric membranous structures are present in the vacuole at the top left. A dense cytoplasmic body is visible at the bottom left of the micrograph. $\times 75,000$.

Fig. 4. Golgi area of a monocyte $48 \mathrm{hr}$ after infection with $B$. abortus, strain sA-s, showing a normal architecture in spite of the fact that this cell contained a very large number of organisms. The mottled appearance of the brucellas visible at the periphery of the Golgi region is due to a cutting artifact. $\times \mathbf{2 6 , 5 0 0}$.

Fig. 5. Detail of Fig. 3 showing at a higher magnification the cell wall and cytoplasmic membrane of two brucellas and the membrane of the enclosing vacuole. $\times 123,000$.

\section{Plate 4}

Fig. 6. Intracellular Brucella abortus, strain sA-s, $24 \mathrm{hr}$ after ingestion by a monocyte showing the structure of the cell wall and cytoplasmic membrane and also of the membrane of the enclosing vacuole. Note the localized area of 'cytoplasmic retraction' (arrow): the space between the cytoplasmic membrane and the outer cell wall layer is filled with homogeneously dense material. $\times 140,000$.

Fig. 7. Intracellular $B$. abortus, strain $\mathrm{SA}-\mathrm{R}, 24 \mathrm{hr}$ after ingestion. $\times 123,000$.

Fig. 8. Detail of a monocyte $24 \mathrm{hr}$ after infection with $B$. abortus, strain sA-R, showing a vacuole containing a normal looking brucella and possibly remnants of others. Also present in the vacuole are some rod-like inclusions which, at higher magnification, show a periodic lamellar structure. $\times \mathbf{5 5 , 0 0 0}$. 


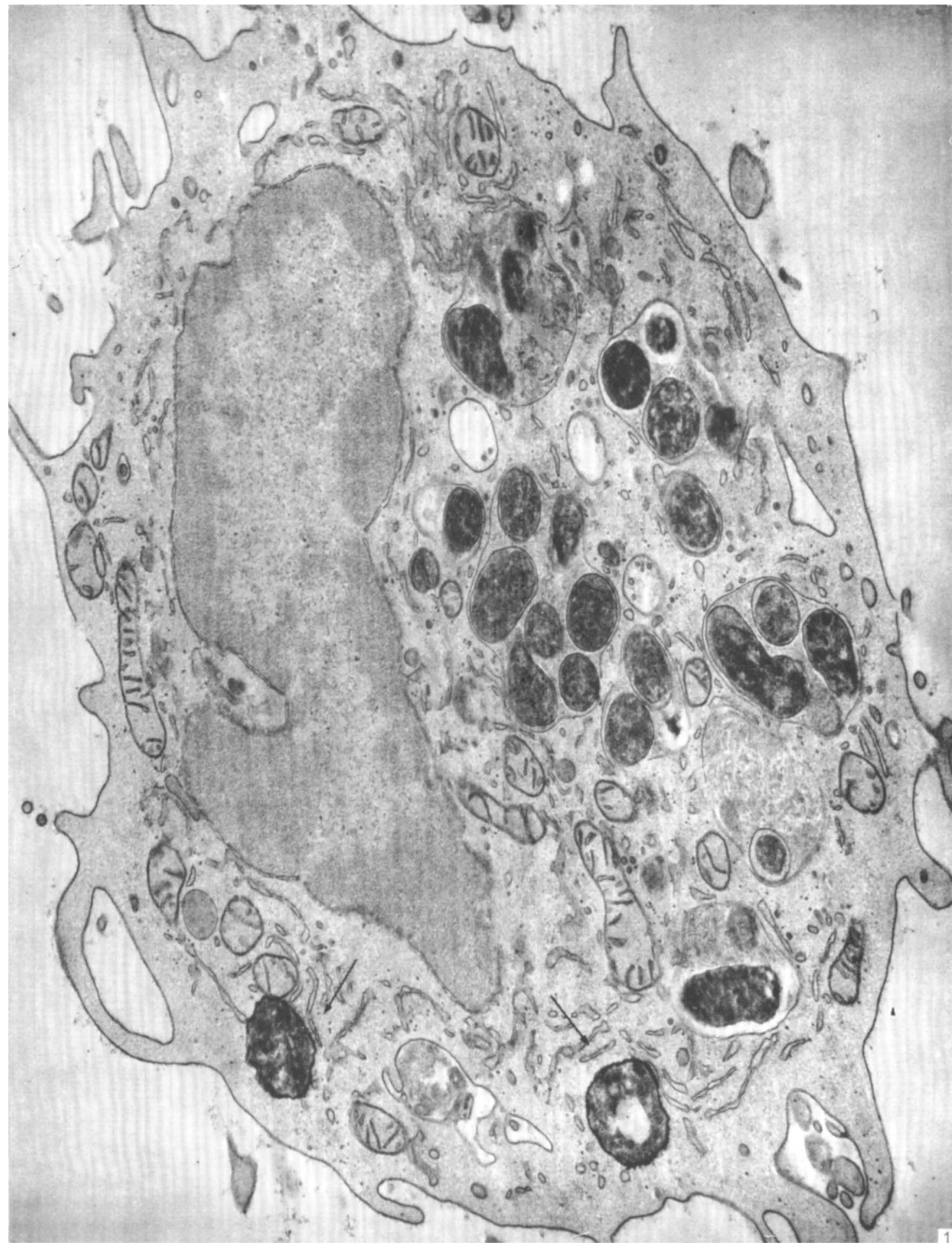




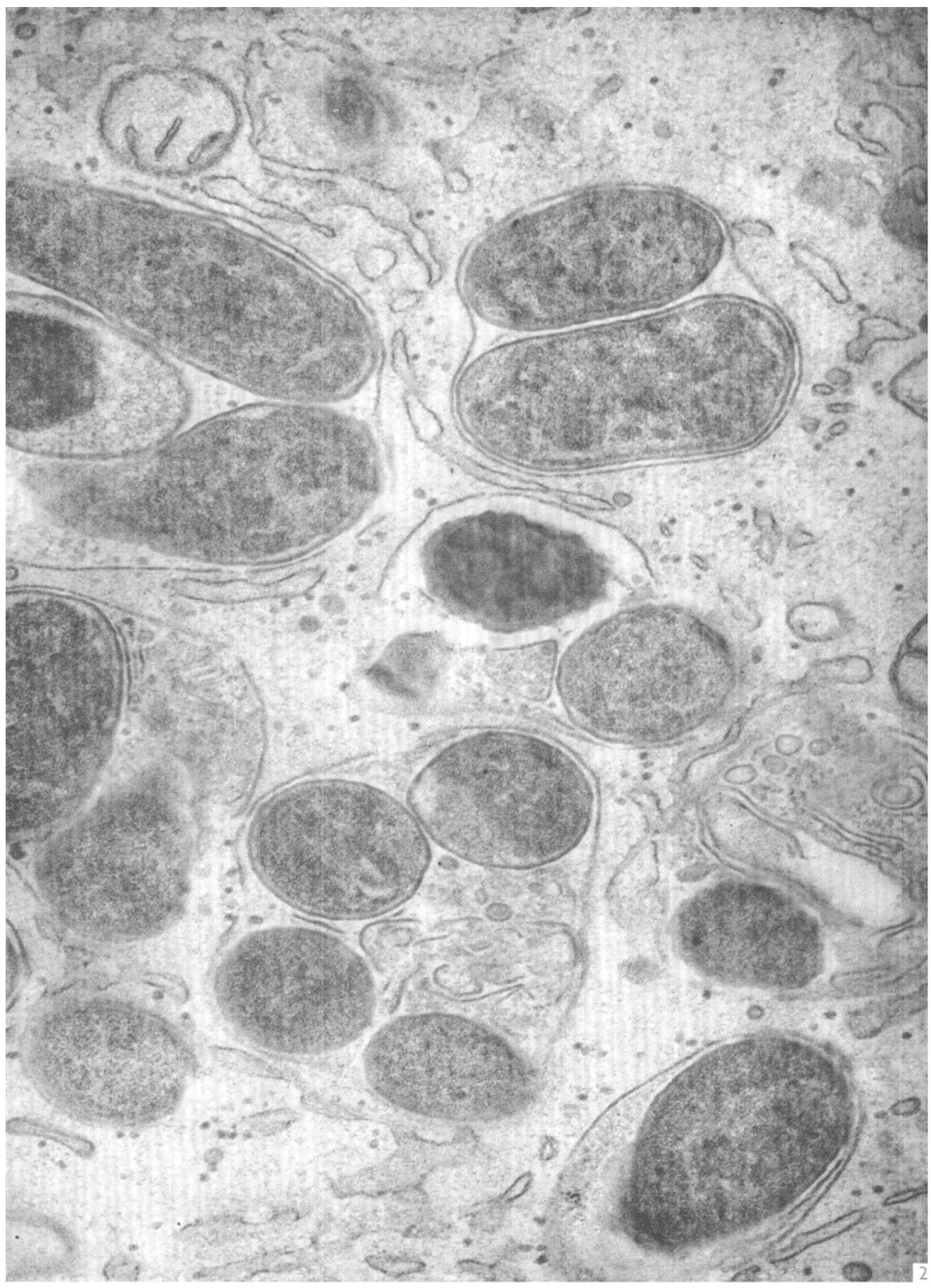




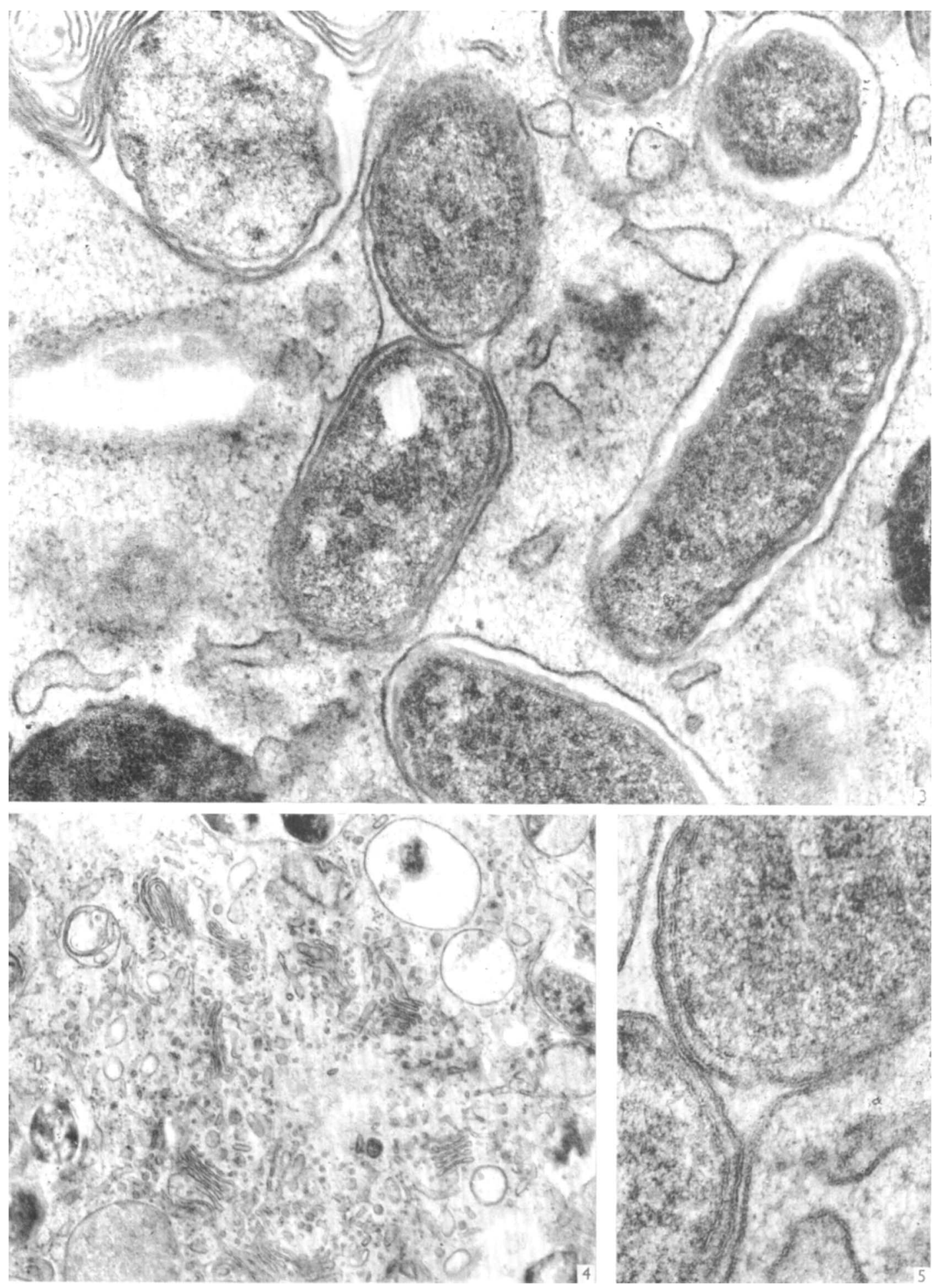

G. KARLSBAD, R. W. I. KESSEL, S. DE PI'TRIS AND L. MONACO 

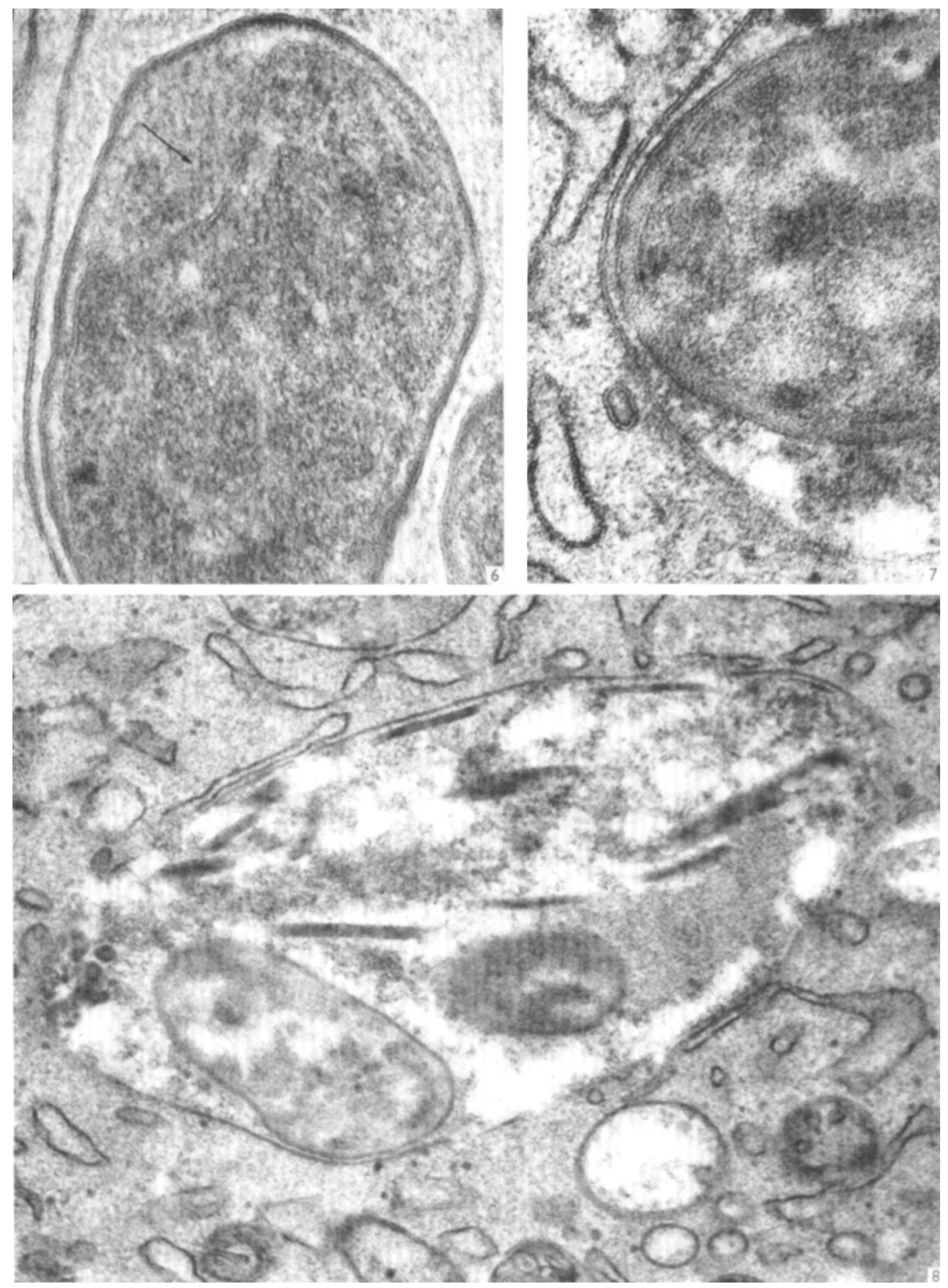

G. KARLSBAD, R. W. I. KESSEL, S. de PETRIS and L. MONACO 